RENATA RetTingeR

Uniwersytet Pedagogiczny im. Komisji Edukacji Narodowej w Krakowie

\title{
Stan i perspektywy rozwoju bazy noclegowej w obwodzie lwowskim
}

\section{WPROWADZENIE}

Okres przemian ustrojowych na Ukrainie został także zaobserwowany w sektorze turystycznym, wolnorynkowe reformy spowodowały systemowe zmiany w funkcjonowaniu regionów i ośrodków turystycznych tego kraju. Największe przeobrażenia zarejestrowano w sferze stosunków własnościowych infrastruktury turystycznej oraz w przestrzennym układzie obszarów recepcyjnych i generujących ruch turystyczny (rozpad ZSRR). Początek lat 90. skutkował dla sektora turystycznego olbrzymim regresem, związanym z okresem przekształceń ustrojowych i ekonomicznych. Turystykę należy także traktować jako czynnik sprawczy wielu zmian społeczno-gospodarczych zachodzących pod jej wpływem. Transformacja ustrojowa na Ukrainie spowodowała szereg niekorzystnych skutków w sektorze produkcji rolniczej i przemysłowej, w związku z tym turystyka może zaistnieć jako czynnik aktywizacji społeczno-gospodarczej wielu regionów. Współcześnie gospodarka turystyczna jest najszybciej rozwijającą się dziedziną gospodarki światowej, ponieważ jej funkcja ekonomiczna wywołuje korzystne zmiany w różnych układach przestrzennych, od lokalnej do międzynarodowej.

Obwód lwowski, jeden z 24 obwodów Ukrainy, leży w zachodniej części na obszarze pogranicza polsko-ukraińskiego. Jego powierzchnia wynosi $21833 \mathrm{~km}^{2}$, podzielonych na 20 rejonów oraz 7 miast wydzielonych: Lwów, Borysław, Drohobycz, Sambor, Stryj, Truskawiec i Czerwonohrad. Ośrodkiem administracyjnym i stolicą obwodu jest Lwów. Na obszarze obwodu znajdują się 43 miasta, 34 miasteczka i 1854 wsie. Liczba ludności wynosi 2,5 mln, gęstość zaludnienia wynosi 126 osób/ $\mathrm{km}^{2}$, a wskaźnik urbanizacji 59\%.

\section{UWARUNKOWANIA PRZYRODNICZE ROZWOJU TURYSTYKI}

Obwód lwowski charakteryzuje duża różnorodność krajobrazowa. Jest ona rezultatem położenia w granicach kilku odmiennych jednostek fizyczno-geograficznych. Północna część leży w obrębie Małego Polesia, jest to równina rozcięta dolinami rzecznymi (Bug Zachodni, Styr, Horynia) na szerokie płaskowzgórza. Wschodnia część leży w obrębie 
Wyżyny Wołyńsko-Podolskiej, która ma charakter płyty rozczłonkowanej głębokimi dolinami rzecznymi. Jednostki te są oddzielone od siebie Polesiem Małym. Wyżyna Wołyńska składa się z szeregu wapiennych i piaskowcowych stoliw, o przeciętnej wysokości 250350 m n.p.m. Na obszarze Wyżyny Podolskiej występuje kilka oddzielnych wzniesień: Góry Krzemienieckie, Gołogóry, Woroniaki, Opole i Miodobory. Na południu obwodu rozciaga się Przedkarpacie, którego głównymi elementami rzeźby terenu są płaskie wierzchowiny o wysokości 300-500 m n.p.m., w części południowo-wschodniej dochodzące nawet do 700 m n.p.m. Garby Wysoczyzny Przedkarpackiej oddzielone są od siebie dolinami rzecznymi prawych dopływów Dniestru i Prutu. Na południowym zachodzie obwodu rozciagają się Karpaty Ukraińskie, które tworzą długie grzbiety o kierunku NW - SE. Przeważają grzbiety o wysokości ponad 1000 m, najwyższy szczyt Howerla liczy 2061 m n.p.m.

Ze względu na rzeźbę i budowę geologiczną Karpat Ukraińskich wyróżnia się następujące jednostki morfostrukturalne: Wysoczyznę Przedkarpacką, Karpaty Zewnętrzne (Karpaty Skibowe i Karpaty Pokucko-Bukowińskie), Karpaty Centralne (Bieszczady), Karpaty Połonińsko-Czarnohorskie, Karpaty Wulkaniczne i Kotliny Śródgórskie. Badany obszar leży w obrębie Karpat Zewnętrznych, a dokładnie Beskidów Górnodniestrzańskich i Beskidów Skolskich. Beskidy Górnodniestrzańskie złożone są z grzbietów o wyraźnym układzie rusztowym. Grzbiety wznoszą się do wysokości 700-1022 m n.p.m. i są zbudowane z odpornych piaskowców kredowych. Przeważają szczyty o kopulastych wierzchowinach i asymetrycznych stokach. Doliny rzeczne są wycięte w mało odpornych łupkach i mają szerokie sterasowane dna. U wylotu dolin bocznych występują rozległe kotliny. Natomiast Beskidy Skolskie tworzą monoklinalne grzbiety o wysokości 1000-1300 m n.p.m. o asymetrycznych stokach. Stoki północno-wschodnie są strome i skaliste, a stoki eksponowane na południowy zachód są łagodne. W dolinach rzecznych występują dobrze wykształcone terasy akumulacyjne i skalno-osadowe. Szczególnie duże powierzchnie zajmują terasy akumulacyjne w obrębie kotlin erozyjno-denudacyjnych np. Skolskiej.

Ważną rolę na omawianych terenach pełnią obszary przyrody chronionej. Występują tu różne formy konserwatorskiej ochrony przyrody. Na terytorium rejonu skolskiego położony jest Park Narodowy Beskidy Skolskie, Rezerwat Krajobrazowy Berdo, w rejonie turczańskim Park Biosfery Karpaty Wschodnie, Nadsański Regionalny Park Krajobrazowy oraz Park Krajobrazowy Pikuj. Na granicy rejonu turczańskiego i starosamborskiego rozpościera się Górnodniestrzański Regionalny Park Krajobrazowy. Obszary chronione mają na celu ochronę unikatowego krajobrazu północnego skłonu Karpat oraz fauny i flory tego regionu. Na szczególną uwagę zasługuje Nadsański Regionalny Park Krajobrazowy - zajmuję on powierzchnię $194,28 \mathrm{~km}^{2}$, ciągnie się stosunkowo wąskim pasem wzdłuż doliny górnego Sanu. Po stronie polskiej graniczy z Bieszczadzkim Parkiem Narodowym i Parkiem Krajobrazowym Doliny Sanu, z którymi razem tworzy Międzynarodowy Rezerwat Biosfery „Karpaty Wschodnie”. Powstał w roku 1997 w celu ujednolicenia ochrony przyrody w obszarze doliny Sanu, główną funkcją parku jest promowanie takich form gospodarowania, które pozwolą na zachowanie różnorodności biologicznej i racjonalne turystyczne wykorzystanie terenu. Swym zasięgiem obejmuje trzy pasma górskie: Czerwony Wierch, Sański Grzbiet, Buczok oraz doliny potoków Rika i Jabłuńka.

Po zakończeniu II wojny światowej obszary pogranicza polsko-ukraińskiego były wyludnione w ramach akcji ,oczyszczania strefy przygranicznej”. W przypadku rejonu turczańskiego obszary te są zaludnione, dotyczy to szczególnie wsi położonych w dolinach Riki i Jabłuńki, w których leżą duże wsie Boberka, Szandrowiec oraz Wyżna i Niżna Jabłuńka. 
Dlatego w odróżnieniu od Bieszczadzkiego Parku Narodowego po drugiej stronie Sanu, lasy i zarośla stanowią tylko 51,6\% obszaru Nadsańskiego RPK, zaś aż 42,9\% grunty rolne. Wśród lasów przeważają bukowe, jodłowe i świerkowe, przy czym świerk pochodzi ze sztucznych nasadzeń. Szata roślinna terenów Nadsańskiego RPK została silnie przekształcona przez człowieka. Sporą część lasów zastąpiły pastwiska, obecnie wtórnie dziczejące i zarastające jałowcem.

Parki narodowe jako obszary szczególnie chronione, dla których nadrzędnym celem jest zachowanie unikatowych ekosystemów dla przyszłych pokoleń, z natury rzeczy starają się ograniczać udział innych niż ochronne funkcje na swoim terenie (Liszewski 2009). Bardzo ważnym zagadnieniem jest monitoring i kontrola wszelkiej działalności gospodarczej, wliczając turystyczną, na obszarach chronionych i w ich najbliższym otoczeniu. Intensywna i niekontrolowana zabudowa infrastrukturą turystyczną może doprowadzić do degradacji środowiska przyrodniczego, przez co obszar przestanie być atrakcyjny.

Ukraina należy do krajów o wysokim wskaźniku intensywności użytkowania ziemi, decydują o tym przede wszystkim bardzo urodzajne gleby. W przypadku rejonu skolskiego i turczańskiego pierwszoplanowym czynnikiem decydującym o strukturze użytkowania ziemi są warunki środowiska przyrodniczego. Konsekwencją trudnych warunków środowiska przyrodniczego w tych dwóch jednostkach jest wysoki wskaźnik zalesienia. W 2005 r. lasy zajmowały w obwodzie lwowskim powierzchnię 693,3 tys. ha, co stanowi 31,7\% powierzchni ogólnej. Natomiast w rejonie skolskim było to 104,8 tys. ha, a wskaźnik lesistości wynosi aż $71,2 \%$, a w rejonie turczańskim 68,0 tys. ha, co daje $57,0 \%$. W celu określenia kierunków użytkowania ziemi w wyżej wymienionych rejonach, można posłużyć się metodą kolejnych ilorazów, na jej podstawie rejony charakteryzują się leśnymi kierunkami użytkowania ziemi.

\section{UWARUNKOWANIA KULTUROWE ROZWOJU TURYSTYKI}

Czynnikiem, który w sposób zasadniczy decyduje o możliwościach rozwoju turystyki, jest dziedzictwo kulturowe. Obwód lwowski posiada olbrzymi potencjał w zakresie pozaprzyrodniczych warunków rozwoju turystyki. Największa liczba zabytków architektonicznych znajduje się we Lwowie. W mieście tym znajduje się 3 tys. zabytków historycznych, architektonicznych i kulturalnych, co stanowi ponad 50\% wszystkich obiektów zabytkowych na Ukrainie. W 1998 r. lwowskie Stare Miasto zostało wpisane na listę obiektów Światowego Dziedzictwa Kultury UNESCO. Do najcenniejszych budowli należą: Katedra Łacińska z kaplicami Kampianów i Boimów, sobór Św. Jury, Katedra Ormiańska, zespół Cerkwi Wołoskiej, kościół Dominikanów, kościół i klasztor Bernardynów, rynek wraz z historyczną zabudową, Państwowy Akademicki Teatr Opery i Baletu, arsenał królewski, Baszta Prochowa i Cmentarz Łyczakowski.

Bardzo cenne obiekty znajdują się także w innych miejscowościach:

- Busk - cerkiew, synagoga i pałac w dawnym majątku ziemskim,

- Brody - cytadela, „Brodiwski” i „Pitgorodecki”, pałac, synagoga i cmentarz żydowski, który jest jedną z największych nekropolii żydowskich tej części Ukrainy,

- Czerwonohrad - zespół pałacowy w dawnym majątku ziemskim Potockich z XVIII w.,

- Oborszyn - pałac biskupów lwowskich XVIII w.,

- Olesko - zamek Jana III Sobieskiego z XIV w., 
- Podhorce - pałac Koniecpolskich z XVII w.,

- Podkamień - kościół i klasztor Dominikanów,

- Stare Sioło - ruiny zamku z XVI w.,

- Sambor - zabytkowy ratusz, kościół św. Jana Chrzciciela,

- Drohobycz - kościół p.w. Wniebowzięcia Najświętszej Marii Panny, cerkiew drewniana, synagoga,

- Skole - cerkiew, muzeum krajoznawcze w dawnej dzwonnicy cerkiewnej,

- Żółkiew - kolegiata, kościół i klasztor Dominikanów, cerkiew grekokatolicka, cerkiew drewniana, synagoga, zamek (Rut 2002).

Oprócz wymienionych zabytków w opisywanych miejscowościach znajduje się wiele innych cennych obiektów związanych z przeszłością tego regionu kształtowaną pod wpływem różnych kultur i religii.

\section{PozycJA OBWODU LWOWSKIEGO W POTENCJALE TURYSTYCZNYM UKRAINY}

Ze względu na walory środowiska przyrodniczego, dziedzictwa kulturowego oraz zagospodarowania turystycznego na obszarze Ukrainy wyróżnić można dwa podstawowe regiony turystyczne o znaczeniu krajowym i międzynarodowym, tj. obszar wybrzeża Morza Czarnego oraz Karpaty (tab. 1). Pojedynczymi ośrodkami turystycznymi na Ukrainie są miasta posiadające szczególne walory turystyczne, takie jak Lwów czy Kijów.

W przypadku funkcji uzdrowiskowej szczególne walory posiadają obszar Półwyspu Krymskiego, a zwłaszcza jego południowe wybrzeże $\mathrm{z}$ łagodnym śródziemnomorskim klimatem. Krym jest największym sanatoryjno-uzdrowiskowym i turystycznym regionem Ukrainy (Zastawnyj, Kusiński 2003). W 2008 r. funkcjonowały tu 553 sanatoria oraz 93 obiekty noclegowe dysponujące 14 tys. miejsc noclegowych. Drugim podobnym obszarem są pozostałe obwody położone nad Morzem Czarnym i Morzem Azowskim, należą tu: odeski, doniecki, zaporoski, mikołajowski i chersoński. Region ten charakteryzuje się zarówno walorami wypoczynkowymi i uzdrowiskowymi. Do najważniejszych ośrodków turystycznych należą: Odessa, Białogród, Berdiańsk i Mikołajów (tab. 1). Trzecim ważnym regionem o szczególnych walorach wypoczynkowych i uzdrowiskowych jest region karpacki, do którego należy analizowany obwód lwowski.

Tab. 1. Obiekty noclegowe na Ukrainie

\begin{tabular}{|c|c|c|c|c|c|c|}
\hline \multirow{3}{*}{$\begin{array}{c}\text { Jednostki } \\
\text { administracyjne }\end{array}$} & \multicolumn{4}{|c|}{ Obiekty noclegowe } & \multirow{2}{*}{\multicolumn{2}{|c|}{$\frac{\text { Sanatoria }}{\text { Liczba obiektów }}$}} \\
\hline & \multicolumn{2}{|c|}{ Liczba obiektów } & \multicolumn{2}{|c|}{ Miejsca noclegowe } & & \\
\hline & 2000 & 2008 & 2000 & 2008 & 2000 & 2008 \\
\hline Ukraina & 1308 & 1595 & 102906 & 161955 & 3327 & 3073 \\
\hline Krym & 90 & 93 & 11357 & 14839 & 519 & 553 \\
\hline Winnicki & 32 & 23 & 2464 & 1563 & 31 & 30 \\
\hline Wołyński & 32 & 30 & 2378 & 2137 & 84 & 68 \\
\hline Dniepropietrowski & 84 & 103 & 6025 & 10925 & 236 & 158 \\
\hline Doniecki & 73 & 75 & 5910 & 5764 & 521 & 357 \\
\hline Żytomierski & 37 & 44 & 2312 & 4736 & 33 & 23 \\
\hline
\end{tabular}




\begin{tabular}{|l|r|r|r|r|r|r|}
\hline Zakarpacki & 39 & 61 & 2839 & 5367 & 65 & 61 \\
\hline Zaporoski & 59 & 31 & 3554 & 2382 & 189 & 201 \\
\hline Iwano-Frankowski & 34 & 35 & 2305 & 2804 & 41 & 35 \\
\hline Kijowski & 46 & 37 & 2693 & 2458 & 157 & 88 \\
\hline Kirowogradzki & 21 & 17 & 970 & 1089 & 34 & 41 \\
\hline Ługański & 43 & 101 & 3297 & 5789 & 144 & 92 \\
\hline Lwowski & 55 & 148 & 4893 & 11081 & 148 & 121 \\
\hline Mikołajewski & 44 & 95 & 2490 & 13271 & 172 & 163 \\
\hline Odeski & 96 & 81 & 8161 & 7788 & 338 & 432 \\
\hline Połtawski & 65 & 48 & 3421 & 2877 & 50 & 44 \\
\hline Równieński & 23 & 22 & 1833 & 2624 & 40 & 23 \\
\hline Sumski & 46 & 29 & 2372 & 2355 & 55 & 28 \\
\hline Tarnopolski & 27 & 40 & 2478 & 4478 & 18 & 17 \\
\hline Charkowski & 76 & 50 & 4859 & 3261 & 79 & 96 \\
\hline Chersoński & 47 & 120 & 2817 & 21681 & 127 & 236 \\
\hline Chmielnicki & 30 & 29 & 1578 & 1806 & 21 & 18 \\
\hline Czerkaski & 36 & 55 & 2491 & 3960 & 80 & 61 \\
\hline Czerniowiecki & 18 & 27 & 1793 & 4675 & 16 & 12 \\
\hline Czernihowski & 52 & 65 & 1887 & 4023 & 61 & 42 \\
\hline Kijów & 95 & 125 & 14478 & 16907 & 50 & 47 \\
\hline Sewastopol & 8 & 11 & 1251 & 1315 & 18 & 26 \\
\hline
\end{tabular}

Źródło: opracowanie własne na podstawie materiałów statystycznych Głównego Urzędu Statystycznego Obwodu Lwowskiego

\section{INWESTYCJE W SEKTOR TURYSTYCZNY}

Bardzo duże możliwości rozwoju turystyki w obwodzie lwowskim niestety nie korelują z potencjałem infrastruktury turystycznej zarówno w przypadku bazy noclegowej, jak i gastronomicznej. W ostatnich latach podejmuje się działania zmierzające do racjonalizacji tej sytuacji. W różnych częściach obwodu powstają obiekty świadczące usługi noclegowe i gastronomiczne. Od początku 2001 r. powstało ponad 3300 nowych miejsc noclegowych, z czego $40 \% \mathrm{w}$ roku 2005. Najwięcej nowych miejsc noclegowych w okresie od 2001 do 2008 r. zostało oddanych do eksploatacji w Truskawcu - 1524 miejsca noclegowe, co związane jest z funkcją uzdrowiskową tego miasta; w większości są to inwestycje zagraniczne. Pozostałe obiekty noclegowe powstają w bezpośrednim sąsiedztwie aglomeracji Lwowa oraz przy głównych szlakach komunikacyjnych prowadzących od granicy z Polską do Lwowa jak i z innych kierunków (tab. 2). Trzecim obszarem są peryferyjne części obwodu lwowskiego położone na przedpolu Karpat lub w Karpatach, jest to przede wszystkim rejon skolski (260 nowych miejsc noclegowych). Tutaj aktywność budowlana sektora turystycznego wiąże się z możliwościami rozwoju turystyki wypoczynkowej i aktywnej narciarskiej (obszary górskie). Obwód lwowski dysponuje bardzo dużym potencjałem uzdrowiskowym, jest on jed- 
nym z ważniejszych regionów uzdrowiskowych na Ukrainie, ale w ostatnich latach stosunkowo niewiele powstało nowych obiektów sanatoryjnych. Jest to spowodowane kłopotami z finansowaniem tego typu usług turystycznych oraz brakiem obiektów noclegowych typu hotelowego. W okresie ostatnich 9 lat (2001-2008) oddano do użytku zaledwie 416 miejsc noclegowych w obiektach sanatoryjnych, z czego $116 \mathrm{w}$ Truskawcu.

Tab. 2. Liczba miejsc noclegowych oddanych do eksploatacji w miastach i rejonach obwodu lwowskiego w latach 2010-2008

\begin{tabular}{|c|c|c|c|c|c|}
\hline \multirow{2}{*}{$\begin{array}{c}\text { Jednostki } \\
\text { administracyjne }\end{array}$} & 2001 & 2005 & 2006 & 2007 & 2008 \\
\hline & \multicolumn{5}{|c|}{ miejsca noclegowe } \\
\hline ob. lwowski & 50 & 1306 & 582 & 599 & 773 \\
\hline Lwów & & 44 & 51 & 104 & 20 \\
\hline Borysław & & & 10 & 98 & 20 \\
\hline Morszyn & & & & 10 & 25 \\
\hline Stryj & & & & 30 & 15 \\
\hline Truskawiec & & 877 & 148 & 179 & 320 \\
\hline grodzki & & & & 11 & 12 \\
\hline żydaczowski & & & & 14 & \\
\hline żółkiewski & & & 14 & 16 & \\
\hline kamionko-buski & & & 251 & & 128 \\
\hline mikołajowski & & 12 & & & \\
\hline mościski & & 155 & 10 & & 4 \\
\hline pustomycki & 50 & 134 & 24 & & 18 \\
\hline skolski & & 84 & 34 & 42 & 100 \\
\hline turski & & & 10 & 30 & \\
\hline jaworowski & & & 30 & 65 & 111 \\
\hline
\end{tabular}

Źródło: opracowanie własne na podstawie materiałów statystycznych Głównego Urzędu Statystycznego Obwodu Lwowskiego

Od początku 2001 r. obserwuje się wzrost inwestycji w infrastrukturę turystyczną obwodu lwowskiego, na początku analizowanego okresu wartość inwestycji krajowych w infrastrukturę noclegową i gastronomiczną wynosiła 5 mln hrywien, a w 2008 r. już 210 mln hrywien, z czego 88\% przypadało na budowę i modernizację hoteli. W przypadku inwestycji zagranicznych obserwuje się już od kilku lat tendencję wzrostu wielkości kapitału inwestowanego $\mathrm{w}$ modernizację istniejących obiektów sanatoryjnych. W ciągu ostatnich trzech lat rokrocznie wartość tychże inwestycji wynosiła ponad $10 \mathrm{mln}$ USD. Dla porównania na budowę hoteli przeznacza się ok. 7 mln USD. Stosunkowo dużo środków zagranicznych lokuje się w powstawanie biur turystycznych, ich propozycje są skierowane do turysty ukraińskiego i obejmują turystykę wyjazdową, czyli nie są bezpośrednio zainteresowane rozwojem miejscowej infrastruktury turystycznej.

Restrukturyzacja gospodarki ukraińskiej oraz głęboki kryzys ekonomiczny spowodowały wzrost bezrobocia, dlatego też upatruje się olbrzymie nadzieje w rozwoju turystyki jako sektora, który stworzy nowe miejsca pracy. Od początku 2001 r. obserwuje się sukcesywny 
wzrost liczby zatrudnionych w tym sektorze gospodarki narodowej. W 2008 r. najwięcej zatrudnionych było w obiektach sanatoryjno-uzdrowiskowych, wielkość ta wynosiła ok. 10 tys. osób, dalej w kolejności w hotelach i innych obiektach noclegowych ok. 3,5 tys. osób.

\section{PRZESTRZENNE ZRÓŻNICOWANIE ZAGOSPODAROWANIA}

\section{TURYSTYCZNEGO OBWODU LWOWSKIEGO}

W przypadku obwodu lwowskiego zauważa się pewną prawidłowość dotyczącą przestrzennego rozmieszczenia obiektów noclegowych, są one lokalizowane w ośrodkach miejskich pełniących funkcje administracyjne, w miejscowościach uzdrowiskowych oraz na terenach o szczególnych walorach wypoczynkowych (np. górskich).

Cechą miejskiej sieci osadniczej obwodu lwowskiego jest jej zróżnicowana gęstość. Najkorzystniejszą sytuację w tym względzie mają uprzemysłowione rejony na północy i południu analizowanego terenu. W rejonie drohobyckim jeden ośrodek miejski obejmuje swym zasięgiem ok. $170 \mathrm{~km}^{2}$, a w sokalskim $200 \mathrm{~km}^{2}$. Podobnie kształtuje się sytuacja w przygranicznym rejonie jaworowskim, gdzie na jedno miasto przypada $250 \mathrm{~km}^{2}$ powierzchni (Flaga 2003). Najniższe wartości notowane są w obszarach peryferyjnych, takich jak brodowski w północno-wschodniej części obwodu oraz turkiwski w Karpatach, tutaj wskaźnik utrzymuje się na poziomie jedno miasto na $600 \mathrm{~km}^{2}$.

Najważniejszym ośrodkiem turystycznym Ukrainy jest Lwów, decyduje o tym wartość historyczna obiektów zabytkowych, które już wcześniej zostały wymienione. Jest to zarazem ośrodek dysponujący największym potencjałem usługowym w zakresie bazy noclegowej, a w szczególności hotelarskiej (tab. 2). Według różnych opinii o atrakcyjności turystycznej danego miasta decydują nie tylko jego walory turystyczne, ale także sposób organizacji ruchu turystycznego, a zwłaszcza promocja i obsługa turystów (Kowalczyk 2005). Lwów już na przełomie XIX i XX w. był wykształconym ośrodkiem turystycznym o zasięgu międzynarodowym. Kiedy Ukraina była jedynie republiką związkową ZSRR, obniżyło sie nieco znaczenie tego miasta w systemie międzynarodowych ośrodków turystycznych. Obecnie powoli miasto odzyskuje swoją pozycję poprzez rozbudowę istniejącej infrastruktury turystycznej, a także poprzez różnego rodzaju działania promocyjne. Na pewno konkurencyjność Lwowa w stosunku do innych miast europejskich jest znacząco obniżona z powodu niskiego standardu usług turystycznych i bardzo słabej dostępności komunikacyjnej, zarówno drogą lądową jak lotniczą. Lwów, którego dziedzictwo kulturowe znajduje się na bardzo wysokim europejskim poziomie, powinien czynić starania, by jak najszybciej uzupełnić braki infrastrukturalne, które znacząco ograniczają zdolność miasta do konkurowania z innymi europejskimi ośrodkami turystycznymi.

Kolejnym ważnym ośrodkiem turystycznym jest Truskawiec, uzdrowisko o bardzo długiej i ciekawej przeszłości. W źródłach pisanych nazwa Truskawiec jako osada pojawiła się w 1469 r. Już w 1578 r. na lecznicze właściwości tutejszych wód uwagę zwrócił Wojciech Oczko, nadworny lekarz króla Stefana Batorego. Do pierwszej połowy XIX w. ruch turystyczny był niewielki, wynikało to z braku niezbędnych urządzeń uzdrowiskowych. Dzięki staraniom władz austriackich w 1827 r. powstał pierwszy drewniany budynek zabiegowy wyposażony w 8 kabin kąpielowych i pomieszczenia mieszkalne dla gości. Według różnych źródeł przypuszcza się, że pierwszym lekarzem uzdrowiskowym był dr Turek. W latach 50. 
XIX w. odkryto nowe złoża wód (Maria, Emanuel, Anna, Zofia), a Teodor Torosiewicz przeprowadził badania ich składu chemicznego i właściwości leczniczych.

Od roku 1859 Truskawiec był własnością prywatną i kilkakrotnie zmieniał właścicieli. Byli to przede wszystkim żydowscy przedsiębiorcy. Okres ten charakteryzował się spadkiem znaczenia uzdrowiska. Jednym z czynników ograniczających rozwój tego uzdrowiska była jego słaba dostępność komunikacyjna, wynikająca chociażby z braku połączenia kolejowego z dużymi miastami. Dopiero w 1872 r. doprowadzono linię kolejową do pobliskiego Drohobycza. Niedostateczny rozwój infrastruktury uzdrowiskowej był także czynnikiem ograniczającym ruch kuracjuszy. W okresie tym wielkość ruchu kuracjuszy wahała się od 783 osób w 1863 r. do 1000 w 1864 r. Większość gości pochodziła z obszaru ówczesnej Galicji, Bukowiny i zaboru rosyjskiego (Buczek, Quirini-Popławski 2009). W latach 80. XIX w. Truskawiec był dzierżawiony przez spółkę obywatelską i w tym okresie powstało kilka willi dla kuracjuszy, restauracje, zakłady kąpielowe, obudowano źródła i założono park zdrojowy.

Początek XX w. zaowocował instalacją wodociągów i kanalizacji oraz elektrycznego oświetlenia w mieście. Od 1911 r. aż do wybuchu II wojny światowej w ramach spółki Zdroje Truskawieckie zdrojem zarządzała rodzina Jaroszów. Był to okres bardzo korzystny dla Truskawca, doprowadzono połączenie kolejowe, zbudowano liczne wille. W pobliskich Pomiarkach powstało unikatowe kąpielisko siarczanowo-solankowe na wolnym powietrzu. Lata 30 . ubiegłego stulecia to okres, w którym powstało szereg nowych willi z przeznaczeniem dla kuracjuszy. Według Leszczyckiego pod koniec okresu międzywojennego funkcjonowało 170 pensjonatów i willi, a Truskawiec posiadał bezpośrednie połączenia kolejowe z Warszawą, Krakowem, Łodzią, Poznaniem, Lwowemi Lublinem(Buczek, QuiriniPopławski 2009). II woja światowa niekorzystnie wpłynęła na stan uzdrowiska. Wstrzymane zostały inwestycje, a działania wojsk spowodowały straty w infrastrukturze uzdrowiskowej. W czasie II wojny światowej kurort był wykorzystywany przez wojsko, do 1940 r. był on sanatorium dla żołnierzy radzieckich, następnie przez 3 lata był okupowany przez wojska niemieckie, które wycofując się, dokonały dotkliwych zniszczeń obiektów sanatoryjnych, wywieziono też znaczną część sprzętu medycznego. Po wkroczeniu wojsk radzieckich w 1944 r. Truskawiec przez kilkanaście miesięcy był zamkniętym szpitalem wojskowym.

Okres powojenny dla Truskawca oznaczał wzrost inwestycji w infrastrukturę sanatoryjną, ale także niszczenie starej substancji uzdrowiska. W pierwszych powojennych latach wiele willi i pensjonatów rozebrano. Rola Truskawca została doceniona dopiero w 1952 r., kiedy uzdrowisko otrzymało status kurortu o najwyższej ogólnozwiązkowej randze, co skutkowało nowym sposobem finansowania jego dalszego rozwoju. W 1960 r. cała infrastruktura uzdrowiskowa została przekazana pod zarząd Ministerstwa Ochrony Zdrowia. Okres ten charakteryzował się zupełnie innym typem budownictwa uzdrowiskowego, stara willowa zabudowa została zastąpiona wysoką zabudową wielkopowierzchniowych ośrodków sanatoryjnych. Zmienił się także charakter przestrzenny zasięgu budownictwa, została ograniczona ilość terenów otwartych i zielonych. Od 1965 r. powstawały duże kompleksy sanatoryjne: Diament (1000 lóżek), Kryształ (1010 łóżek), Szahtar, Rubin (1000 łóżek), Karpaty. Obiekty te były własnością państwową lub komunalną. Równocześnie powstawały mniejsze obiekty noclegowe (Prolisok, Mołdowa, Naftusia). Pod koniec lat 80. pojawiły się pierwsze prywatne obiekty noclegowe, które stanowiły uzupełnienie oferty państwowych sanatoriów. W tym czasie Truskawiec otrzymał też połączenie kolejowe z Moskwą i Leningradem (Nicieja 2008). Intensywny rozwój budownictwa sanatoryjnego przyniósł 
wiele niekorzystnych zjawisk, zaburzony został ład przestrzenny poprzez przypadkowe lokalizacje budynków, wysoki wskaźnik intensywności zabudowy i lokalizowanie wielokondygnacyjnych obiektów na eksponowanych krajobrazowo terenach (Buczek, QuiriniPopławski 2009).

Uzyskanie przez Ukrainę niepodległości w 1991 r. zapoczątkowało nowy okres w gospodarce tego kraju. Gospodarka wolnorynkowa i deklarowane reformy społeczno-gospodarcze miały pozytywne i negatywne konsekwencje dla tego uzdrowiska. Jedną z ważniejszych są przemiany własnościowe. W 1995 r. powołano do życia spółkę Truskawiec - Kurort SA, która posiada 7 sanatoriów: Jantar, Rubin, Oksana, Maria, Kryształ. Głęboki kryzys ekonomiczny oraz zmiany finansowania działalności uzdrowisk wpłynęły na rentowność działalności państwowych i komunalnych obiektów sanatoryjnych. Konieczne okazało się wprowadzenie zmian systemowych w zakresie funkcjonowania uzdrowiska. Bardzo ważną inicjatywą gospodarczą było utworzenie specjalnej strefy turystyczno-rekreacyjnej Kurortopolis Truskawiec (2000 r.). Do jej strategicznych celów należy radykalna poprawa jakości świadczonych usług sanatoryjnych, przyspieszenie działań związanych z reformą działalności uzdrowiskowej, stworzenie warunków do powstawania nowych inwestycji oraz ochrona i racjonalne wykorzystanie zasobów przyrody. Obecnie obserwuje się kilka kierunków działalności w kurorcie. Jednym z ważniejszych jest rewitalizacja przedwojennych willi w centrum kurortu, drugim budowa nowych obiektów noclegowych i modernizacja obiektów sanatoryjnych.

Bardzo ważnym problemem jest sezonowość wykorzystania tych obiektów, co nie jest charakterystyczne dla tego typu ruchu turystycznego. W większości krajów regiony uzdrowiskowe nie notują typowej sezonowości w ruchu turystycznym kuracjuszy.

Perspektywicznie znaczącym uzupełnieniem oferty bazy noclegowej obwodu lwowskiego może być rozwój podmiotów zajmujących się turystyką wiejską. Ten rodzaj turystyki na Ukrainie jest w fazie przejściowej: od pełnienia funkcji uzupełniającej bazy kwater na terenach o szczególnych walorach wypoczynkowych i rekreacyjnych do stworzenia własnych ofert produktów turystycznych. Zachodnia Ukraina charakteryzuje się bardzo wysokim udziałem gospodarstw prywatnych, co stanowi naturalną podstawę do stworzenia sieci gospodarstw agroturystycznych, w innych regionach liczba tych gospodarstw jest znacznie niższa. Niestety, aby odpoczynek w gospodarstwie agroturystycznym był konkurencyjny dla innych form ruchu turystycznego, musi poprawić się poziom wyposażenia infrastrukturalnego na obszarach wiejskich. W 2007 r. na terenie Ukrainy funkcjonowało 870 gospodarstw agroturystycznych z czego na rejony karpackie (4 obwody) przypadało 528 podmiotów (Zin'ko, Malska, Malskiy, Amtoniuk 2008).

Trzecim obszarem intensywnie zagospodarowanym turystycznie są rejony położone w południowej części obwodu lwowskiego, gdzie występują bardzo korzystne warunki morfometryczne i klimatyczne dla turystyki zimowej. Już okres przedwojenny charakteryzował się intensywnymi działaniami zmierzającymi do poprawy zagospodarowania turystycznego wschodniej części Karpat, poprzez budowę schronisk i rozwój infrastruktury towarzyszącej. W okresie władzy radzieckiej rozwój turystyczny tego regionu był ściśle kontrolowany, w latach 1960-1970 powstawały liczne ośrodki sportowe, wypoczynkowe oraz wyciagi narciarskie. Był to obszar intensywnie wykorzystywany turystycznie, tutaj prowadzone były przygotowania kadry olimpijskiej Związku Radzieckiego, do dnia dzisiejszego pozostały ośrodki wypoczynkowe położone wzdłuż drogi prowadzącej do Skola. Równolegle rozwijała się turystyka indywidualna, która wykorzystywała przede wszystkim kwatery prywatne. 
Jednym z najważniejszych ośrodków tego regionu było i jest Sławsko, położone niedaleko Skola, jest to jeden z najważniejszych ukraińskich ośrodków narciarskich. W XIX w. Austriacy wybudowali tutaj kilkanaście pensjonatów, natomiast w okresie międzywojennym powstały wyciagi oraz skocznia na górze Pohar. Obecnie obszar ten dysponuje zagospodarowaniem na czterech stokach: Trościan, Pohar, Menczuł i Politechnik. Jedynie tylko część z nich jest sztucznie naśnieżana i oświetlona. Równolegle do bazy towarzyszącej powstaje baza noclegowa, w szczególności dotyczy to hoteli, których ewidentnie brakowało.

\section{Podsumowanie}

Obwód lwowski posiada zespół najlepszych warunków do rozwoju różnego rodzaju form ruchu turystycznego. Jest to region o szczególnych walorach środowiska przyrodniczego, występują tu zarówno obszary nizinne jak i górskie z dużym udziałem obszarów chronionych. O funkcji turystycznej tego regionu decyduje także bardzo bogate dziedzictwo kulturowe, a w szczególności dotyczy to takiego ośrodka jak Lwów. Miasto posiada ponad 3 tys. obiektów zabytkowych, jest jedynym w swoim rodzaju miastem-muzeum, wpisanym na listę Światowego Dziedzictwa Kultury UNESCO. Obwód lwowski jest jednym z najważniejszych regionów uzdrowiskowych Ukrainy, z głównym ośrodkiem w Truskawcu, który w ostatnich latach przechodzi szereg zmian strukturalnych. Niestety funkcja turystyczna tego regionu jest ograniczana poprzez bardzo słaby stan infrastruktury turystycznej i dostępność komunikacyjną. Od wielu lat obserwuje się deficyt obiektów noclegowych, zarówno w samym Lwowie, jak i na pozostałych obszarach obwodu. Dodatkowym mankamentem jest niska jakość świadczonych usług, wynikająca z niskiego standardu obiektów.

\section{Literatura}

Buczek M., Quirini-Popławski Ł., 2009, Frekwencja kuracjuszy w Krynicy w Karpatach Zachodnich i Truskawcu w Karpatach Wschodnich (Ukraina), Prace Geograficzne, z. 121, Instytut Geografii i Gospodarki Przestrzennej UJ, Kraków.

Flaga M., 2003, Zmiany zaludnienia miast obwodu lwowskiego w latach 90. jako odzwierciedlenie ich sytuacji społeczno-gospodarczej, Annales Universitatis Mariae Curie-Skłodowska.

Kowalczyk A., 2005, Nowe formy turystyki miejskiej, Prace i Studia Geograficzne, nr 35, Warszawa

Liszewski S., 2009, Przestrzeń turystyczna parków narodowych w Polsce, [w:] Gospodarka i przestrzeń. Prace dedykowane Profesor Danucie Ptaszczyckiej-Jackowskiej, red. B. Domowski, W. Kurek, Instytut Geografii i Gospodarki Przestrzennej UJ, Kraków.

Nicieja S.S., 2008, Truskawiec - dzieje kresowego kurortu, Indeks, nr 9-8.

Rut J., 2002, Turystyka aktywna w Euroregionie Karpackim, Wydawnictwo Uniwersytetu Rzeszowskiego, Rzeszów.

Zastawnyj F., Kusiński W., 2003, Ukraina. Przyroda-ludność - gospodarka, Wydawnictwo Akademickie Dialog, Warszawa.

Zin'ko J., Malaska M., Malaskiy M., Amtoniuk N., 2008, Wdrażanie składników zrównoważonej turystyki na terenie Karpat Ukraińskich, [w:] Uwarunkowania rozwoju turystyki zagranicznej w Europie Środkowej i Wschodniej, t. 10, Turystyka w Środowisku Geograficznym, Wrocław. 


\section{Present state and outlook of tourist accommodation base development in Lviv Oblast}

Lviv Oblast can be proud of most favourable conditions for the development of various forms of tourism. It is a region of unique environmental features, characterized both by lowlands and mountain ranges with large share of protected areas. Tourist functions of the region are proven by numerous cultural heritage sites, especially in such a centre as the city of Lviv. In Lviv there are over three thousand monuments, which makes it a unique "city - museum", recognized by UNESCO within its list of World Heritage Sites. Lviv Oblast is one of the most important spa regions in Ukraine, with the main spa resort of Truskawiec, which has been recently undergoing a whole range of structural changes. For many years a deficit of tourist accommodation has been observed, both in Lviv itself and in other areas of the region. Another drawback is low quality of the offered services, which is caused by the low standard of available facilities.

dr Renata Rettinger

Uniwersytet Pedagogiczny im. Komisji Edukacji Narodowej w Krakowie

e-mail: rettinger@onet.eu 